\title{
Imre Waldbauer, an Important but Little-Known Violinist Partner of Béla Bartók
}

\author{
Zsombor NÉMETH*
}

Budapest Bartók Archives, Institute for Musicology, Research Centre for the Humanities, Táncsics Mihály u. 7., H-1014, Budapest, Hungary

Franz Liszt Academy of Music, Liszt Ferenc tér 8., H-1061, Budapest, Hungary

\section{ORIGINAL RESEARCH PAPER}

Received: May 7, 2018 • Accepted: February 8, 2020

(c) 2021 The Author

\begin{abstract}
Imre Waldbauer (1892-1952) attained his greatest stature as a performer in his position as the first violinist of the Waldbauer-Kerpely Quartet, named after him and cellist Jenö Kerpely. This ensemble premièred Bartók's String Quartets nos. 1, 2 and 4 and his early Piano Quintet. Although Waldbauer's name is mostly mentioned in the Bartók-literature primarily because of his quartet, he was also important for Bartók as a "standalone" violinist as well. Waldbauer and Bartók played numerous sonata recitals from the 1910s to the 1930s, and Waldbauer also played the first performance of important violin works by Bartók: the "One Ideal" from the Two Portraits, (première: Budapest, 12 February 1911), the Violin Sonata no. 2 (première: Berlin, 7 February 1923) and nos. 16, 19, 21, 28, 36, 42, 43, 44 from the Forty-Four Duos (concert hall première: Budapest, 20 January 1932). Although Waldbauer seems like an individual of special importance, very little is known about his relation to Bartók and about his life in general (unlike his violinist contemporaries, e.g. Joseph Szigeti or Zoltán Székely). The present paper focuses on the relationship between the composer and the violinist, using materials from the yet unexplored Waldbauer legacy held in the Budapest Bartók Archives (recent donation from the Waldbauer family).
\end{abstract}

\section{KEYWORDS}

Bartók, Imre Waldbauer, concerts, premieres, legacy

*Corresponding author. E-mail: nemeth.zsombor@abtk.hu 
The last table in the Appendix in Balázs Szabó's PhD thesis about the Bartók Violin Sonatas lists the composer's violinist partners. ${ }^{1}$ According to his research, Bartók's most frequent violinist partner was Zoltán Székely, the dedicatee of the Violin Concerto (BB 117), with 20 performances, the second place goes to Ede Zathureczky with 19 occasions, and Joseph Szigeti, one of the commissioners of Contrasts (BB 116) and dedicatee of the Rhapsody no. 1, for violin and piano (or orchestra) (BB 94a, b), still earns a podium in this imaginary competition with 16 concerts.

Bartók's fourth most frequent violinist partner was Imre Waldbauer. His fame, compared to the violinists mentioned above, has faded heavily since his death in 1952. Although Waldbauer, according to the statistics by Szabó, seems to have been an important person in Bartók's career, surprisingly little is known about his life and work. ${ }^{2}$ In a broader context, he is remembered today nearly only as the leader of the Waldbauer-Kerpely Quartet, internationally known as the Hungarian Quartet. ${ }^{3}$ If someone is curious specifically about him, it is hard to find anything at all not just in writings for the general public, but also in musicological works. ${ }^{4}$ All that we know of him comes either from himself or from his close contemporaries. ${ }^{5}$ The number of later recollections are also limited. ${ }^{6}$ The only major work about Waldbauer is a 1977 D.M.A. dissertation by Julia Quick focusing on his violin pedagogy. ${ }^{7}$ Quick's research was mainly based

\footnotetext{
${ }^{1}$ Balázs SZABÓ, “Forma és jelentés Bartók hegedűszonátáiban” [Forms and meanings in Bartók’s violin sonatas] Ph.D. Dissertation (Budapest: Liszt Ferenc Academy of Music, 2015), 374. See online at http://docs.lfze.hu/netfolder/public/ PublicNet/Doktori\%20dolgozatok/szabo_balazs/ (accessed 25 September 2017).

${ }^{2}$ As an example, both current major encyclopedic dictionaries of Western music, The New Grove Dictionary of Music and Musicians, second edition (NG2) and the Musik in Geschichte und Gegenwart, second edition (MGG2), lack a standalone article about Imre Waldbauer, who was still present in MGG1, see Antal MOLNÁR, "Waldbauer, Imre," in Die Musik in Geschichte und Gegenwart, ed. by Friedrich BLUME (Kassel: Bärenreiter, 1968), vol. 14, 143.

${ }^{3}$ Both NG2 and MGG2 have articles about the Hungarian Quartet. The name Hungarian Quartet was used in Hungarian as "Magyar Vonósnégyes" and in German as "Ungarisches Streichquartett," both can be literally translated as Hungarian String Quartet. This should not be confused with the internationally much more famous ensemble with the same name (founded in 1935 in Budapest, disbanded in 1972 after a long career in the United States), which was originally established as "Új Magyar Vonósnégyes" (New Hungarian String Quartet), and dropped "New" from its name after the disbandment of the Waldbauers. After the disbandment of the (New) Hungarian String Quartet in 1972 the violist Dénes Koromzay established another "New Hungarian String Quartet," which existed until 1984; in 2018 another "New Hungarian Quartet” was founded by András Keller.
}

${ }^{4}$ A notable exception - although with many inaccuracies - is: Zoltán FARKAS, "Waldbauer Imre," in Nagy tanárok, híres tanítványok, ed. by Ágnes GÁDOR and Gábor SZIRÁNYI (Budapest: Liszt Ferenc Zeneművészeti Egyetem, 2000), 326327. See online, translated into English as the "Notable Alumni" page of the Liszt Academy of Music: http://lfze.hu/ nagy-elodok/-/asset_publisher/HVHn5fqOrfp7/ (accessed 10 January 2018).

${ }^{5}$ Imre WALDBAUER, "Waldbauer Imre," in Zenei lexikon [Dictionary of music], ed. by Bence SZABOLCSI and Aladár TÓTH (Budapest: Győző Andor, 1931), vol. 2, 690; A magyar muzsika könyve [The book of Hungarian music], ed. by Imre MOLNÂR (Budapest: Merkantil kiadás, 1936), 516; A Magyar muzsika höskora és jelene történelmi képekben [The early history and the present state of Hungarian music in historical pageants], ed. by László BATIZI (Budapest: Dr. Pintér Jenőné kiadása, 1944), 391.

${ }^{6}$ Márta GÖNDÖR SZESZLERNÉ (Mrs. Szeszler), “Emlékezés Waldbauer Imrére” [Remembering Imre Waldbauer], Parlando 6/3 (1964), 15-16; András SCHIFF and Sándor VÉGH, “Száz éve született Waldbauer Imre” [Imre Waldbauer was born 100 years ago], Muzsika 35/5 (May 1992), 14-15.

7Julia QUICK, “Violin Pedagogy of Imre Waldbauer,” D.M.A. Diss. (Iowa City: University of Iowa, 1977). 
on interviews, and her publication is mostly valuable today as a systematic collection of oral history primarily related to Waldbauer's final years. The lack of exact information about Waldbauer's life in general and about his relation to Bartók is in sharp contrast with not just the aforementioned Székely-Zathureczky-Szigeti trio, but also with other important violinists in Bartók's life. ${ }^{8}$

Imre Waldbauer's son, Ivan - who was a renowned musicologist and Bartók scholar - died in 2012, and in 2013 part of his papers was given to the Budapest Bartók Archives by his widow, Claudia Macdonald. This package, which actually contains mostly the legacy of his father, is now stored in the Budapest Bartók Archives in eight blue boxes, named and numbered as "Waldbauer I" to "Waldbauer VIII." The first seven boxes contain sheet music, the eighth contains personal papers, such as unpublished letters, writings, clippings from newspapers, and photographs. ${ }^{9}$ In the following section of my essay I summarize the life and work of Imre Waldbauer, using already available published sources as well as his unpublished CVs and letter drafts found in box $W$-VIII.

\section{SUMMARY OF IMRE WALDBAUER'S LIFE AND WORKS}

Imre (Emmerich) Waldbauer was born in Budapest on 13 April $1892 .{ }^{10}$ His father, a born Austrian, was József (Josef) Waldbauer, a graduate of the Academy of Music in Budapest and the violist of the Hubay-Popper String Quartet. He was also a significant violin pedagogue and music educator who wrote a Violin School which was notable for using special tetrachord fingerings to avoid open strings whenever possible. ${ }^{11}$ In 1898 he left the Quartet because he was assigned as secretary of the "Budapesti Kamara Zeneegyesület" (Budapest Chamber Music Society, president: Ödön Mihalovich, director of the Academy of Music). ${ }^{12}$ Imre’s godfather, too, was an illustrious person in the Hungarian musical life: Hans von Koessler (a cousin of Max

\footnotetext{
${ }^{8}$ For Székely, see Claude KENNESON, Székely and Bartók: The Story of a Friendship (Portland: Amadeus Press, 1994). For Szigeti, see among others Joseph SZIGETI, With Strings Attached: Reminiscences and Reflections (New York: Alfred A. Knopf, 1947) and László SOMFAI, "Bartók and Szigeti," The New Hungarian Quarterly 33/128 (Winter 1992), 157163. Although Zathureczky, in contrast to Székely and Szigeti, is missing from the major international encyclopedic dictionaries, he has at least one major biography written in Hungarian: István HOMOLYA, Zathureczky Ede (Budapest: Zenemükiadó, 1972). According to the number of joint concerts and pieces with dedication, further important Bartók violinists are Jelly d’Arányi, Stefi Geyer, Franz von Vecsey, André Gertler, and Yehudi Menuhin, see SZABÓ, "Forma és jelentés," 374.

${ }^{9}$ From here, I will refer to these as yet uncatalogued items as "Document title," W-VIII, etc. The only document in $W$ VIII which has been already catalogued as C-2135/16 is an untitled concert diary of the Waldbauer-Kerpely Quartet (listing performances from 1910 to the end of the 1927/1928 season). Since this paper was written, some of the documents have been published in an edited form, see Zsombor NÉMETH, "Bartók-témájú írások a Waldbauerhagyatékban" [Bartók related documents in the Waldbauer legacy], Magyar Zene 58/1 (February 2020), 89-119.

${ }^{10}$ The MGG1 article by Antal MOLNÁR gives wrong date: 3 March. 13 April can be considered correct as it is also presented in Waldbauer's own CV from the end of the 1940s: "Curriculum Vitae of Imre Waldbauer," W-VIII.

${ }^{11}$ For more about József Waldbauer, see Imre WALDBAUER, “Waldbauer József,” in Zenei lexikon, vol. 2, 690.

${ }^{12}$ Carl KRATOCHWILL et al., Neue musikalische Presse: Zeitschrift für Musik, Theater, Kunst, Sänger-und Vereinswesen (Wien: Hans Schneider, 1899), vol. 8, 31.
} 
Reger), who was in charge of the composition classes at the Academy of Music between 18821908 and 1920-1925, and who was inter alia the teacher of Béla Bartók and Zoltán Kodály. ${ }^{13}$

Imre Waldbauer's first violin teacher was his own father, who also introduced him to the field of chamber music. Between the academic years 1904/1905 and 1909, Imre Waldbauer was a student at the Academy of Music in Budapest, where he was taught by Jenő Hubay (violin) and David Popper (chamber music). ${ }^{14}$ Early on, he was known as an excellent chamber music player. He played not just in his family's salon, but in public performances, many times together with the cellist Ferenc (Franz) Tonházi. ${ }^{15} \mathrm{He}$ established his later well-known string quartet originally as a temporary ensemble requested by Rózsavölgyi \& Co. sometime in the autumn of $1909 .{ }^{16}$ It consisted of his friends from the Academy of Music - János Temesváry (second violin), Antal (Anton) Molnár (viola) - and the cellist Jenő (Eugen) Kerpely, who was seven years his senior and had returned from abroad in $1908 .^{17}$

An untitled, six-page-long sketch dated 1950 found in W-VIII tells us the story of how Waldbauer first met Bartók. ${ }^{18}$ When he was 11 or 12 years old (ca. 1903-1904), he heard the pianist-composer's name more and more often at family meals and at weekly scheduled private chamber music sessions. From this information, Waldbauer simply thought that Bartók was some kind of hypersensitive, half-educated, arrogant, ultranationalist revolutionary who would

\footnotetext{
${ }^{13}$ Vera LAMPERT, “Koessler [Kössler], Hans,” Grove Music Online http://www.oxfordmusiconline.com/grovemusic/ view/10.1093/gmo/9781561592630.001.0001/omo-9781561592630-e-0000015256 (accessed 18 January 2018). In W$V I I I$, there is a picture of Koessler and an unidentified person wandering in the mountains, with the annotation "Kössler bácsi" (uncle Koessler).

${ }^{14}$ According to the different volumes of Az Országos M. Kir. Zene-Akadémia Évkönyve [Almanac of the Royal Hungarian Academy of Music], ed. by Géza MORAVCSIK, Waldbauer was a student but was not qualified in 1904/1905, and he was an ordinary student between the academic years 1905/1906-1908/1909. In 1909/1910 he was a "repeater" of his own will, but at the end he did not acquire a diploma. He was not an official student of Koessler in composition, as stated in "Curriculum Vitae of Imre Waldbauer," W-VIII.

${ }^{15}$ See his "Collection of clippings 1906-1910," W-VIII. and the programs of the fifth Public [Chamber Music] Evening on 4 May 1908, the Examination Concert on 12 May 1909, and Haydn Memorial Concert on 6 June 1909. All concert data, unless noted otherwise, can be found in the work-in-progress Koncertadatbázis - budapesti hangversenyek 1900-tól napjainkig [Concert database - Budapest Concerts from 1900 to Present] of the Archives and Research Group for 20th-21st-Century Hungarian Music, Institute of Musicology, Research Centre for the Humanities: http://db.zti.hu/ koncert (accessed 18 January 2018). Tonházi later became a noted cello teacher in Transylvania, see András BENKÖ, “A romániai magyar felsőfokú zenei oktatás történetének vázlata” [Sketches for the history of Hungarian higher music education in Romania], Erdélyi Múzeum 59 (1997), 220.
}

${ }^{16}$ See Antal Molnár's recollection in Dezső LEGÁNY, A magyar zene krónikája [The chronicles of Hungarian music] (Budapest: Zenemükiadó, 1962), 431.

${ }^{17}$ Waldbauer already participated in an academic concert devoted to contemporary music as early as 21 October 1907 , and Waldbauer and Tonházi were playing together in different formations with three later members of the WaldbauerKerpely Quartet - Temesváry, Molnár and Egon Kornstein - on 14 May 1909 in a concert consisting only of contemporary music. According to an article written in 1925, Zoltán Kodály's String Quartet no. 1 was already rehearsed by an ensemble consisting Waldbauer, Temesváry, Molnár and Tonházi, see "Tizenöt éves a WaldbauerKerpely kvartett” [The Waldbauer-Kerpely Quartet turns 15], Világ 16/99 (3 May 1925), 19. Note that Kodály and Molnár were close friends in this period. Bartók and Kerpely had already played Dohnányi's Piano Quintet op. 1 on 21 March 1903 together as part of a public concert of the Academy of Music, and they had a joint recital on 10 January 1906 in Pozsony [Pressburg, now Bratislava]. The players who performed in the Waldbauer-Kerpely Quartet from 1910 onwards are listed in Appendix 1.

${ }^{18}$ Published in NÉMETH, „Bartók-témájú írások a Waldbauer-hagyatékban,” 96-99. 
shortly vanish from the public awareness. Not much later they met personally at one of the chamber music events where Waldbauer was playing and Bartók was in the audience. ${ }^{19}$ After the event, they were introduced to each other, and although they did not speak much, the false preconception of Waldbauer disappeared in seconds. They got to know each other better presumably in 1909, when Bartók and Kodály were in search for a string quartet to premiere their works.

As is well known, after about one hundred rehearsals, the debut concert of the WaldbauerKerpely Quartet was at the first concert devoted to Zoltán Kodály's works on 17 March 1910 in the so-called Royal Hall (the concert hall of the Royal Hotel near the Academy of Music), which was followed by Bartók's concert two days later at the same venue. ${ }^{20}$ Within a year, the quartet had gained a European reputation for their interpretations of modern chamber music works that had never been performed, had been comparatively unknown, or had been performed previously without proper interpretation. Apart from the works of Bartók, Kodály and Leó Weiner, they also became propagators of the works of Schoenberg and several other German, French, English, and Dutch composers. ${ }^{21}$ This was partly due to the merit of Gusztáv Bárczy, one of the owners of Rózsavölgyi \& Co. who was also responsible for concert management. After the outstanding success of the four young instrumentalists in both Kodály's and Bartók's concerts, Bárczy engaged the Quartet for a concert series for which they were obliged to play a new piece in every concert. $^{22}$

Debussy, when hearing them in Budapest on 5 December 1910 in his own concert also arranged by Bárczy, declared that in their performance he felt as if he really had heard his own work for the first time. ${ }^{23}$ The French composer even invited the Hungarian musicians to Paris. ${ }^{24}$

${ }^{19}$ As currently there is no data about Bartók visiting the Waldbauer salon, this could have been also in the house of the Kunwalds, close friends of the Waldbauers, where Bartók was a regular guest at chamber music sessions. Bartók, Jr., notes that Bartók visited the Kunwalds on 3 June 1900, 18 April 1901, 21 April 1901, 14 May 1901, 19 May 1902,25 October 1902, see Béla BARTÓK, Jr., Apám életének krónikája [Chronicle of my father's life] (Budapest: Zenemükiadó, 1981), 33, 35, 21, 36, 43, 46. According to Bartók's letters to his mother dated 6 and 16 December 1901, he also visited the Kunwalds earlier that month; Bartók Béla családi levelei [Family letters of Béla Bartók], ed. by Béla BARTÓK, Jr. and Adrienne GOMBOCZ-KONKOLY (Budapest: Zenemükiadó, 1981), 51-53.

${ }^{20}$ According to Bartók's letter to his mother on 12 January 1910, Waldbauer planned to arrange an own debut concert for the Quartet in early March, with the string quartets by Bartók, Kodály and Leó Weiner. See BARTÓK, Jr. and GOMBOCZ-KONKOLY (eds.), Családi levelei, 193-194.

21 "Curriculum Vitae of Imre Waldbauer," W-VIII.

${ }^{22}$ Imre WALDBAUER, “A magyar kamarazene” [Chamber music in Hungary], in A magyar muzsika hőskora, 137-144.

23“Curriculum Vitae of Imre Waldbauer," W-VIII. Debussy was indeed fascinated by the accomplished playing of the Quartet, see his letter to his wife on 3 December 1910 and his letter to Gusztáv Bárczy on 19 December 1910 in Claude DEBUSSY, Letters 1884-1918, ed. by François LESURE (Paris: Hermann, 1980), 200 and 202. About Debussy's 1910 Budapest concert, see Gergely FAZEKAS, “»Unhealthy« and »Ugly« Music or a »Compass Pointing Towards a Purer Art of Superior Quality«? The Early Reception of Debussy in Hungary (1900-1918),” Studia Musicologica 49 (2008), 330-335. According to László Lajtha, Waldbauer had a letter sent by Debussy, in which he also praised the performance of the Quartet. This letter was hanging in a frame in Waldbauer's studio which was destroyed in the 1944-1945 siege of Budapest. LEGÁNY, A magyar zene krónikája, 428.

24“Curriculum Vitae of Imre Waldbauer," W-VIII and LEGÁNY, A magyar zene krónikája [Chronicle of Hungarian music], 428. The Quartet performed in Paris on 2 December 1912, and had three concerts there on 20, 24 and 25 January 1914. On 20 January, they performed in Debussy's apartment. See the "Concert diary of the WaldbauerKerpely String Quartet (1910-1928),"W-VIII C-2135/16, 2 and 4. 
The series of their appearances abroad began with their tour in the Netherlands and Germany in 1911. ${ }^{25}$ On these occasions, it was their policy to introduce audiences in the countries they visited to international modern music, and thus exchange the knowledge of modern music between different countries. ${ }^{26}$

They did not perform concerts between summer of 1914 and autumn of 1917, during the first years of the First World War, as both Waldbauer and Kerpely served in the army. ${ }^{27}$ Likewise, they were silent between April 1944 and July 1945, for similar reasons. Between 1910 and 1946, they gave a vast number of concerts, including performances in festivals for contemporary music.

During its thirty-six years of existence, the Quartet became world-famous for their interpretations not only of contemporary compositions, but also of classic string quartets and chamber music works. The further foundation of the Quartet's fame was due to their interpretation of Beethoven, especially the late quartets. During the centenary year of the composer's death (1927), they performed all his string quartets in Hungary. ${ }^{28}$

In February 1919, Waldbauer became a professor of violin at the Budapest Academy of Music. After the fall of the Hungarian Soviet Republic and the success of the counter-revolution, Waldbauer - like Bartók, Kodály, Ernő (Ernst von) Dohnányi, and Kerpely - was forced to take a leave. He also participated in the strike committee against the forced resignation of Dohnányi in October 1919. ${ }^{29}$ He returned only to the 1927/1928 academic year as a paid-per-lesson string quartet instructor. ${ }^{30}$ From 1931/1932, he taught violin on preliminary and higher (academic) levels, too. ${ }^{31}$ On 18 July 1934, he was appointed as a professor of violin, chamber music, violin methodology, and violin literature, and also became the leader of the violin teacher's training program. $^{32}$

Waldbauer was also active as a specialist music writer; he wrote articles about violinist topics to the 1930 Zenei lexikon [Dictionary of music] edited by Bence Szabolcsi and Aladár Tóth, and articles about different modern chamber music works for Cobbett's Cyclopedic Survey of

25“Concert diary of the Waldbauer-Kerpely String Quartet (1910-1928),"W-VIII C-2135/16, 1.

26“Curriculum Vitae of Imre Waldbauer," W-VIII. For detailed recollections of Molnár, see Antal MOLNÁR, Magamról, másokról [On myself and others] (Budapest: Gondolat, 1974), 18-21.

${ }^{27}$ Aladár TÓTH, “A Waldbauer-Kerpely Vonósnégyes huszonöt éves jubileuma” [The 25th jubilee of the Waldbauer-Kerpely Quartet], in Tóth Aladár válogatott zenekritikái [Aladár Tóth: Selected music reviews], ed. by Ferenc BÓNIS (Budapest: Zenemükiadó, 1968), 111. (Originally appeared in Pesti Napló, 20 March 1935).

28“Curriculum Vitae of Imre Waldbauer," W-VIII and “Concert diary of the Waldbauer-Kerpely String Quartet (19101928),"W-VIII C-2135/16, [35]-[39].

${ }^{29}$ Dokumentumok a Magyar Tanácsköztársaság zenei életéböl [Documents from the musical life of the Hungarian Soviet republic], ed. by József UJFALUSSY (Budapest: Akadémiai Kiadó, 1973), 218-219, 229, 467, 477, 490, 500-501, 511521. See also Bartók's letter to his mother on 23 October 1919: Béla Bartók Letters, ed. by János DEMÉNY (Budapest: Corvina Press, 1971), 144.

${ }^{30}$ Róbert MESZLÉNYI, Az Országos Magyar Királyi Liszt Ferenc Zenemüvészeti Föiskola évkönyve az 1927/28-iki tanévröl [Almanac 1927/28] (Budapest: Az Országos M. Kir. Liszt Ferenc Zeneművészeti Főiskola Kiadása, 1928), 20.

${ }^{31}$ Kálmán ISOZ, Az Országos Magyar Királyi Liszt Ferenc Zenemüvészeti Föiskola évkönyve az 1931/32-iki tanévröl [Almanac 1931/32] (Budapest: Az Országos M. Kir. Liszt Ferenc Zenemüvészeti Főiskola Kiadása, 1932), 4.

${ }^{32}$ Kálmán ISOZ, Az Országos Magyar Királyi Liszt Ferenc Zenemüvészeti Föiskola évkönyve az 1934/35-iki tanévröl [Almanac 1934/35] (Budapest: Az Országos M. Kir. Liszt Ferenc Zeneművészeti Főiskola Kiadása, 1935), $30,38$. 
Chamber Music. Furthermore, he published a Hungarian obituary about Jenő Hubay, and two essays in 1943 about the golden age of Hungarian violin music and chamber music in Hungary. ${ }^{33}$

Waldbauer's flat, with all his belongings, had been almost completely destroyed during the Second World War, in the 1944-1945 siege of Budapest. According to documents surviving in $W$-VIII, nearly all his possessions, including valuable belongings such as instruments, were destroyed. ${ }^{34}$ Right after the war, he became one of the members of the Board of Directors of the Academy of Music alongside Kodály, Zathureczky, Lajos Bárdos, Béla Böszörményi-Nagy, Bence Szabolcsi, Sándor Veress and Leó Weiner. ${ }^{35}$

According to Artur Garami, assistant concertmaster of the Hungarian Radio Orchestra in 1945-1946, after the war Waldbauer briefly attempted to embark on a solo career. ${ }^{36} \mathrm{He}$ also wanted to reactivate his quartet, but he had too many difficulties. Waldbauer lobbied at the Ministry of Culture, at the Radio, and even at the National Theater to save his ensemble, but his activities were unsuccessful. ${ }^{37}$ To make matters worse, the Quartet's second violinist, Péter Szervánszky, left the ensemble when he won a scholarship to study in Vienna, and Waldbauer became exhausted by looking for new members. ${ }^{38}$ According to common knowledge, the Quartet disbanded after playing Bartók's String Quartet no. 6 (BB 119) for the first time in Hungary in $1946 .{ }^{39}$ In fact, they gave the Budapest premiere of that work on 28 July 1945, at which occasion Kerpely - who was wounded during the siege - had to be substituted by Ede Banda. ${ }^{40}$ The Quartet's existed until October 1946, and during this one and half year they have performed, among others, Bartók's Second, Third and Sixth Quartets on numerous occasions. ${ }^{41}$

${ }^{33}$ Imre WALDBAUER, “Hubay Jenő, a pedagógus” [Jenő Hubay, the pedagogue], A Zene18/10 (16 March 1937), 202203; Imre WALDBAUER: “A magyar hegedűmüvészet és hegedűpedagógia fénykora” [The golden age of Hungarian violin art and pedagogy] and "A magyar kamarazene," in A magyar muzsika höskora, 80-136, 137-144.

34"Követ úr," W-VIII. See also the Circular of the "Magyar Müvészeti Tanács" [Hungarian Art Council] dated 6 May 1946, preserved in W-VIII.

${ }^{35}$ István KAPITÁNFFY, Az Országos Magyar Liszt Ferenc Zenemüvészeti Főiskola évkönyve az 1945/46.-i tanévröl [Almanac 1945/1946] (Budapest: Országos Liszt Ferenc Zeneművészeti Főiskola, 1946), 3.

${ }^{36}$ QUICK, “Violin Pedagogy of Imre Waldbauer," 6.

37"Követ úr," W-VIII.

${ }^{38}$ Waldbauer first tried to substitute Szervánszky with Sándor Végh unsuccessfully, see "Követ úr," W-VIII. See also Miklós RAKOS, “Aki Magyarországon mutatta be Bartók hegedűversenyét” [The violinist who premiered Bartók’s Violin Concerto in Hungary], Zenekar 4/1 (January-March 1997), 22.

${ }^{39}$ See for example: Tully POTTER, "Hungarian Quartet (i)," Grove Music Online, http://www.oxfordmusiconline.com/ grovemusic/view/10.1093/gmo/9781561592630.001.0001/omo-9781561592630-e-0000013560 (accessed 25 January 2018); Tünde SZITHA, "Kerpely Jenő" and Zoltán FARKAS, "Waldbauer-Kerpely Quartett," in Nagy tanárok, híres tanítványok, 150-51, 328-329.

${ }^{40}$ See Tibor TALLIÁN, Magyar képek. Fejezetek a magyar zeneélet és zeneszerzés történetéböl 1940-1956 [Hungarian sketches. Chapters from the history of Hungarian music life and composition 1940-1956] (Budapest: Balassi, 2014), 114; Jemnitz Sándor válogatott zenekritikái [Alexander Jemnitz collected music critiques], ed. by Vera LAMPERT (Budapest: Zenemükiadó, 1973), 378. About Kerpely's condition see the transmitted oral histories in György ÉDER, “Magyar gordonkások a 20. században. Dénes Vera és Banda Ede életműve a Popper Iskola tükrében” [Hungarian cellists in the 20th century. The life of Vera Dénes and Ede Banda and the Popper School] DLA Diss. (Budapest: Liszt Ferenc Zenemüvészeti Egyetem, 2011), 11.

${ }^{41}$ NÉMETH, „Bartók-témájú írások a Waldbauer-hagyatékban,” 115-118. 
Waldbauer received two invitations from abroad in 1946: a professorship in Vienna and another in Iowa City. ${ }^{42}$ Contrary to contemporary rumors, he had not applied for either of them and was offered both positions without an application. ${ }^{43}$ As the high-level chamber music playing did not have any high hopes and expectations in Europe then, Waldbauer chose to accept the position in Iowa in August 1946, where he arrived around Christmas. ${ }^{44}$ Besides his duties as the concertmaster of the University Symphony Orchestra, he became the first violinist in the faculty quartet and the head of the violin department of the music school. ${ }^{45}$ In addition to teaching violin, he coached chamber music, conducted string seminars, and held pedagogy classes. ${ }^{46}$

Waldbauer had originally left the Academy of Music in Budapest only for a one-year leave. ${ }^{47}$ It was shortly before the expiration of his holiday that he made efforts to keep his position in Hungary alongside his professorship in Iowa. ${ }^{48}$ Waldbauer presumably gave up his exertions to return to his homeland after the expulsion of Germans from Hungary and the communist takeover in 1947-1948. ${ }^{49}$ In an interview with the Duluth News Tribune, he stated that he had chosen the United States because he wanted to go as far from the communists as possible. ${ }^{50}$

Although he felt extremely alien in the USA, which is confirmed by his very personal poems written in German around 1948-1950 and preserved in W-VIII, he found opportunities in the

\footnotetext{
${ }^{42}$ See "Curriculum Vitae of Imre Waldbauer," W-VIII; an untitled German CV on paper with heading of the Budapest Academy of Music, W-VIII and N. N., "President Hancher Names Waldbauer, Brown to Faculty," The Daily Iowian (14 September 1946), 6. (see online The Daily Iowan: Archive covering 1868-present: http://dailyiowan.lib.uiowa.edu/(accessed 22 January 2018)). See also KAPITÁNFFY, Az Országos Magyar Liszt Ferenc Zenemüvészeti Föiskola évkönyve az 1946/47.-i tanévröl [Almanac 1946/1947] (Budapest: Országos Magyar Liszt Ferenc Zenemüvészeti Főiskola, 1947), 30.
}

43 "Követ úr," $W$-VIII.

${ }^{44}$ N. N., "New Concert Master Expected to Arrive in I.C. Next Week," The Daily Iowan (14 December 1946), 6; N. N., "Noted Hungarian Violinist Arrives Here Next Week to Join S.U.I.," Iowa City Press-Citizen (14 December 1946). (Clipping and typewritten transcript in W-VIII.)

${ }^{45}$ N. N., "New Concert Master Expected to Arrive in I.C. Next Week." His Iowa debut - according to news advertisements - was on 5 February 1947, see N. N., "Orchestra to Give Concert Wednesday," The Daily Iowan (31 January 1947), 4.

${ }^{46}$ QUICK, "Violin Pedagogy of Imre Waldbauer," 7.

${ }^{47}$ KAPITÁNFFY, Az Országos Magyar Liszt Ferenc Zenemüvészeti Föiskola évkönyve az 1946/47.-i tanévröl, 30.

${ }^{48}$ Waldbauer's holiday was officially lengthened until 1 September 1948, see István KAPITÁNFFY, Az Országos Magyar Liszt Ferenc Zenemüvészeti Főiskola évkönyve az 1947/48.-i tanévről [Almanac 1947/1948] (Budapest: Országos Magyar Liszt Ferenc Zeneművészeti Főiskola, 1948), 22. His position was terminated afterwards: István KAPITÁNFFY, $A z$ Országos Magyar Liszt Ferenc Zenemüvészeti Föiskola évkönyve az 1948/49.-i tanévröl [Almanac 1948/1949] (Budapest: Országos Magyar Liszt Ferenc Zeneművészeti Főiskola, 1949), 5.

${ }^{49}$ See his released letter drafts „Dear Martin” and „Követ úr” in W-VIII. He also states in “Dear Martin” that he was offered high positions if he returned to Hungary. According to Szervánszky’s letter of 25 November 1946 to his father from Vienna to Budapest, Waldbauer said in the train station before leaving that he had high hopes about the recovery of Hungarian musical life and hoped he would come back shortly. RAKOS, "Aki Magyarországon mutatta be Bartók hegedüversenyét," 22.

${ }^{50}$ N. N., "Famed Budapest-Born Musician Enjoys Summer Climate Here," Duluth News Tribune (5 September, 1948). (Clipping in W-VIII.) It is noteworthy that Sándor Jemnitz who, as a strong advocate of modern music, supported Waldbauer from the beginnings - as a committed communist attacked him in a discrediting article half a year after his departure in the newspaper of the communists: Sándor JEMNITZ, "Furcsaságok a Zenemüvészeti Főiskolán," Népszava (21 January 1947) (Clipping in W-VIII.) 
field of chamber music while teaching at the university. He regularly performed in recitals organized by the State University Iowa, playing the classic chamber music literature as well as modern compositions. ${ }^{51}$ He also substituted for Feri Róth in his quartet during their tour in spring $1949 .{ }^{52} \mathrm{He}$ even appeared as soloist of the University Orchestra.

Waldbauer acquired his American citizenship on 13 May $1952 .{ }^{53} \mathrm{He}$ died of cancer quite suddenly half a year later on 4 December $1952 .^{54}$

\section{JOINT CONCERTS OF BARTÓK AND WALDBAUER}

The composer's evening on 19 March 1910 is the first documented occasion of Bartók and Waldbauer performing together publicly. They played the Hungarian premiere of the Piano Quintet. ${ }^{55}$ After the immediate success of their artistic collaboration, a "spin-off" ensemble, the Waldbauer-Kerpely-Bartók Trio was formed. Their debut was in the Royal Hall on 31 October with the early version of Brahms's B-major Piano Trio (op. 8), as part of the Quartet Society's first concert of the $1910 / 1911$ series. ${ }^{56}$ They played the same work and Beethoven's D-major Trio (op. 70 no. 1) in Szeged on 10 November. On 29 October 1911. ${ }^{57}$ The trio extended with Antal Molnár performed the A-major Piano Quartet by Brahms (op. 26) as part of the first concert of the Quartet Society's 1911/1912 series.

The collaboration of Bartók, Waldbauer, Kerpely, and the Hungarian String Quartet seems to have been planned to be very active, according to a flyer by Rózsavölgyi hangversenyrendezőség [Rózsavölgyi concert organiser], published around the end of 1911 or early $1912 .^{58}$ The Quartet

\footnotetext{
${ }^{51}$ Obrecht Eldon, Instructor of String Bass at SUI then recalled some other particularly memorable performances of Waldbauer in QUICK, "Violin Pedagogy of Imre Waldbauer," 14-15. W-VIII holds many clippings about Waldbauer's concerts in Iowa.

${ }^{52}$ See clippings in W-VIII: N. N., "Roth Quartet: Gives »Wonderful, Interest-Holding Program«," Iowa City Press-Citizen (11 March 1949); N. N., "Waldbauer to Perform with Roth Quartet," The Daily Iowan (19 March 1949), 8; N. N., "String Quartet Gives Display of Precision and Dynamics," Galesburg Register-Mail (22 March 1949); Bill RYAN, "Roth Quartet is Warmly Received By Appreciative Aggie Audience," The Daily O'Collegian (25 March 1949), N. N., "Chamber Group Ends Season," San Antonio Express (29 March 1949), 1.

${ }^{53}$ N. N., "Four Become Naturalized Citizen Here Today," Iowa City Press-Citizen (13 May 1952), 9.; N. N., “4 Local Residents Become U.S. Citizens," The Daily Iowan (15 May 1952), 10 (Clippings in W-VIII.).

${ }^{54}$ The MGG1 article gives 5 November 1952, the NG2 ("Hungarian Quartet (i)") indicates 3 December 1953, Nagy tanárok, híres tanítványok [Notable Alumni] gives 5 December 1953. The death of Waldbauer was officially announced the day after his death on the front page of The Daily Iowan, see N. N., "Waldbauer dies - SUI Music Professor Dies Here," The Daily Iowan (5 December 1952), 1 and 5.

${ }^{55}$ All dates of the following paragraphs, unless noted otherwise, come from the Koncertadatbázis and BARTÓK, Jr., Apám életének krónikája.

${ }^{56}$ The performance of the early version is verified in János DEMÉNY, "Bartók Béla müvészi kibontakozásának évei” [Béla Bartók’s years of artistic evolution], in Zenetudományi Tanulmányok, vol. III, ed. by Bence SZABOLCSI and Dénes BARTHA (Budapest: Akadémiai Kiadó, 1955), 378.

${ }^{57}$ László PÉTER, Bartók Szegeden [Bartók in Szeged] (Szeged: Somogyi Könyvtár, 1981), 22-29.

${ }^{58}$ Bartók és a Waldbauer Kerpely vonósnégyestársaság hangversenykörútja (Budapest: Pannonia, s. a.). This flyer mentions the 1911 tours, but still lists Antal Molnár as the violist, who was replaced by Egon Kenton as Molnár announced his retirement from concertizing in Zeneközlöny (11 April 1912), 622.
} 
and also Waldbauer as an independent violinist were planned to take an active part in the UMZE (Új Magyar Zene-Egyesület/New Hungarian Music Society) of 1911-1912, the plans were only partially realized. Bartók was a key figure in the establishment of the UMZE in the spring of 1911, but after the many complications with the Music Society, Bartók retired from Budapest's concert life in early 1912. ${ }^{59}$ Aside from small-scale matinee performances, Bartók did not return to the Hungarian stage until 18 November 1917, playing Debussy's Cello Sonata with Kerpely. This was also the "re-debut" concert of the Waldbauer-Kerpely Quartet after a three-year intermission caused by the war.

The Waldbauer-Kerpely-Bartók Trio was also reactivated to perform Ravel's Piano Trio as a Hungarian premiere on 4 January 1919 as part of the Quartet's third concert of the 1918/1919 series in the Great Hall of the Academy of Music. However, Dohnányi, who returned to Hungary in 1915, became the most frequent piano trio partner of Waldbauer and Kerpely from 1918 onwards, and partly because of this the trio with Bartók never became as significant as had been predicted at the beginning of the decade.

In 1921, Bartók performed his and Dohnányi's Piano Quintets with the Waldbauer-Kerpely Quartet (7 January and 6 March, both in the Great Hall of the Academy of Music, Bartók's Quintet was performed on his composer's evening, Dohnányi's in the Quartet's series). ${ }^{60}$ The WaldbauerKerpely-Bartók Trio played Ravel's Piano Trio on 16 March, Waldbauer-Kerpely Quartet's eighth abonnement concert and Beethoven's D major "Ghost" Trio (op. 70 no. 1) on the fifth subscription concert of the next season, on 28 January $1922 .{ }^{61}$ After that, the Waldbauer-Kerpely-Bartók Trio played only once again together, 16 years later: on 14 December 1937 they performed Mozart's Emajor (K. 542) and Mendelssohn's D-minor (op. 49) Piano Trio in the Great Hall of the Academy of Music, which was also the last time Waldbauer and Bartók performed together.

Waldbauer and Bartók played together as a violin-piano duo fifteen times. (Their joint recitals are listed in Appendix 2). Their collaboration only began in the early 1920s as yet another "spin-off" of the Waldbauer-Kerpely Quartet and was at first centered around Bartók's two recently written Violin-Piano Sonatas. This was the most lasting and most intensive collaboration between the two musicians.

Their first performance as a violin-piano duo was on 20 December 1922 when they played the composer's Sonata for Violin and Piano no. 1 (BB 84) as a Hungarian premiere and as part of Bartók's own composer's concert. This premiere had probably already been planned in the summer of 1922, and Bartók was in search of an appropriate performer; in a letter to Michel-Dimitri Calvocoressi he wrote that he would try to convince both Székely and Waldbauer to learn the piece. ${ }^{62}$

\footnotetext{
${ }^{59}$ See Lynn HOOKER, "Modernism on the Periphery: Béla Bartók and the New Hungarian Music Society of 1911-1912," Musical Quarterly 88/2 (2005), 284, 286-287, 302; David COOPER, Béla Bartók (New Haven and London: Yale University Press, 2015), 122-123.

${ }^{60}$ On 7 January the program of 19 March 1910 was repeated. According to Kodály, Bartók was not in favor of that idea, or rather, he did not approve of it on account of the quintet, but finally gave in. Quoted in the preface by Denijs Dille of Béla BARTÓK, Quintetto (Budapest: Editio Musica Budapest, 1970), [4.].

${ }^{61}$ The later concert is only mentioned in "Concert diary of the Waldbauer-Kerpely String Quartet (1910-1928)," W-VIII C-2135/16, 11.

${ }^{62}$ BARTÓK, Jr., Apám életének krónikája, 198-199., SZABÓ, "Forma és jelentés," 218. We have information about Bartók rehearsing the First Sonata (and also some drafts of the Second) with Zoltán Székely in August 1922, as he was not sure that the then seriously injured Waldbauer would be able to play the premiere in December. See also COOPER, Béla Bartók, 189-190.
} 
The immediately ensuing joint performances of the two musicians were limited to the performance of Bartók's Sonatas, now as part of the concerts of the Waldbauer-Kerpely String Quartet. They repeated the First Sonata on New Year's Eve in 1923, as part of the Quartet's series, ${ }^{63}$ and they played it also on 6 and 9 February 1923 in Berlin in the joint tour of Bartók and the Hungarian String Quartet organized by Melos. Alongside the performances of the first two String Quartets and some other piano pieces, this series included the world premiere of the Sonata for Violin and Piano no. 2 (BB 85) on 7 February 1923 played by Waldbauer and Bartók, twice at the same event.

Two months later, on 5 April 1923, they played their first full recital in Košice, Czechoslovakia [formerly Kassa, Kingdom of Hungary and now part of Slovakia], ${ }^{64}$ which was one of the most adventurous events in Bartók's career as a concert pianist. He reported this in his letter to his mother and his aunt right after the concert. ${ }^{65}$ He complained about the problems with the official papers, the poor construction of the stage, the bad lighting, and the mistakes in the printed program. He even had to shout at Waldbauer during the performance of the Second Sonata, because the violinist forgot to remove the mute and did not even notice it. ${ }^{66}$ Waldbauer's and Bartók's recital in Košice consisted of sonatas by Brahms, Handel and César Franck. ${ }^{67}$ Waldbauer was also Bartók's partner half a year later in Vienna on 24 October 1923, when they performed Bartók's Second Sonata and Bloch's Sonata as part of the week-long Modern Music festival. Bartók's Sonata for Violin and Piano no. 2 also featured on the program of the fourth concert of the Quartet's 1923/1924 series, on 5 January 1924.

After the "boom" in the early 1920s, a seven-year-long hiatus comes in the history of the musical partnership of Bartók and Waldbauer. Because of lack of documents, we cannot determine why they did not perform together in the second half of the decade. The most likely answer might be that Waldbauer simply did not have time to fulfill solo performance requests: according to the concert diary of the Waldbauer-Kerpely Quartet, this was a very intense period in the Quartet's life - many long tours abroad, changes in the team - and also a dense era of the

\footnotetext{
${ }^{63}$ On the scandal surrounding this concert, see Ferenc BÓNIS, Így láttuk Bartókot: Harminchat emlékezés [Thus we saw Bartók: 36 recollections] (Budapest: Zenemükiadó, 1981), 108 [Iván Engels recollection] and Jenő A. MOLNÁR, “A müélvezet rendészete" [Law enforcement and the arts], Muzsika 6/9 (September 1963), 20-22.

${ }^{64}$ About the preparation of the concert, see Bartók's 1923 correspondence with András Vitéz (2 February, 1 March): Basel, Paul Sacher Foundation, Béla Bartók Collection, deposit from Peter Bartók, BB MISC V 101 (photocopy in the Budapest Bartók Archives). This concert was most probably organized as some kind of a propitiation: the program of the Quartet and Bartók performed on 1 January in Budapest was scheduled to 14 January to Košice, but it was cancelled, as was Bartók's solo recital of 16 January. János DEMÉNY, “Bartók Béla művészi kibontakozásának évei: Bartók Béla megjelenése az európai zeneéletben (1914-1926)” [The years of Béla Bartók’s artistic development: Béla Bartók's appearance in European musical culture (1914-1926)], in Zenetudományi Tanulmányok, vol. VII, ed. by Bence SZABOLCSI and Dénes BARTHA (Budapest: Akadémiai Kiadó, 1959), 243.

${ }^{65}$ See Bartók's letter to his mother on 5 April 1923: BARTÓK Jr. and GOMBOCZ-KONKOLY (eds.), Családi levelei, 337338; DEMÉNY (ed.), Béla Bartók Letters, 161-162.

${ }^{66}$ According to the recollections of Antal Doráti, Bartók told him a similar story in the 1940s: during one of the performances of the First Sonata in Budapest, Bartók thought that Waldbauer would forget to put on the mute, but he did so in the very last moment. BÓNIS, Így láttuk Bartókot, 83.

${ }^{67}$ This was the only time when Bartók played a work by Franck. SZABÓ, "Forma és jelentés," 9, 11.
} 
Waldbauer-Kerpely-Dohnányi Trio. This is also the period when Waldbauer started to teach in the Academy of Music again. ${ }^{6}$

The next opportunity for Bartók and Waldbauer to play together was on New Year's Eve in 1931; they performed Sonatas by Bach, Schubert and Mozart as well as Bartók's Rhapsody for Violin and Piano no. 1 (BB 94a) at the Hungarian Radio. This was an early ouverture to their German tour of June 1931 which included three duo recitals in Munich, Augsburg and Nuremberg, and two performances for the Munich and Frankfurt am Main Radio. Their programs featured pieces from the program of 1 January 1931, plus Bartók's Second Sonata, and transcriptions for violin and piano by Székely and Gertler of Bartók's compositions.

Their last duo performance was a full recital in 1934 in the Great Hall of the Budapest Academy of Music, when they played works by Brahms, Mozart, Debussy and Beethoven. The recital marked Bartók's return to the Hungarian stage after nearly four years of absence, following much persuasion by the notable Budapest concert organizer, Imre Kun. ${ }^{69}$

\section{BARTÓK PREMIERES BY WALDBAUER}

Waldbauer's name is mentioned in the Bartók literature primarily because of the WaldbauerKerpely String Quartet, which gave the world premiere of String Quartets nos. 1, 2 and 4 (BB 52, $75,95)$. Additionally, the Hungarian premiere of the early Piano Quintet and the String Quartets nos. 3 \& 6 (BB 93, 119). Nos. 16, 19, 21, 28, 36, 42, 43, 44 from the Forty-Four Duos (BB 104) were also played for the first time by members of the quartet, Waldbauer himself and János Temesváry in the Hungarian Radio and György Hannover in the Academy of Music. ${ }^{70}$ Aside from world and local first performances, they performed Bartók's String Quartets regularly. ${ }^{71}$ In return, Bartók dedicated his String Quartet no. 2 to the ensemble and recommended them to his international contacts many times. ${ }^{72}$

\footnotetext{
${ }^{68}$ According to Koncertadatbázis, Waldbauer - at least in Budapest - did not play any solo repertoire between his last concert with Bartók and his recital with Lajos Kentner on 17 December 1930 in public. Bartók's letter to Herr Windisch from Budapest, dated 6 November 1923 also supports this hypothesis: in this letter Bartók writes about his fears, that the participation of Waldbauer and his Quartet will not be easy because of their busy schedule. This letter was sold in a Sotheby's auction in 2003: http://www.sothebys.com/en/auctions/ecatalogue/2003/music-including-importantautographs-by-beethoven-and-wagner-103404/lot.22.html (accessed 12 February 2018).

${ }^{69}$ See Imre KUN, Harminc év müvészek között [Thirty years among artists] (Budapest: Zenemükiadó, 1960), 154. and BARTÓK, Jr., Apám életének krónikája, 337. As a "warm-up", two concerts were scheduled on 15 and 16 December 1933 in Oradea (formerly Nagyvárad, Hungary) and Cluj (formerly Kolozsvár, Hungary) with a partly similar program (Violin Sonatas by Beethoven and Brahms, and works by Bartók: First Rhapsody and Rumanian Folk Dances, BB 68 in Székely's transcription and short works for piano solo); the two events were cancelled due to the illness of Waldbauer and Bartók played a solo recital instead, see András BENKÖ, Bartók Béla romániai hangversenyei [The concerts of Béla Bartók in Romania] (Bukarest, Kriterion, 1970), 116.

${ }^{70}$ All the dates are from the homepage of the Budapest Bartók Archives: http://zti.hu/bartok/ba_en_06_m.htm?0101 (accessed 24 January 2018).

${ }^{71}$ See NÉMETH, „Bartók-témájú írások a Waldbauer-hagyatékban,” 114-118.

${ }^{72}$ See for example his letters of 5 April 1910 to Volkmar Andreae to Zürich, of 20 August 1921, to Michel-Dimitri Calvocoressi to London and of 10 November 1937 to Gotthold Ephraim Lessing to Baden-Baden, all cited in BARTÓK, Jr., Apám életének krónikája.
} 
As we have seen in the previous section Waldbauer was important for Bartók as a "standalone" violinist as well. It is important to note that as a soloist he also premiered two important violin works by Bartók. Although it is mere coincidence, both works are in some way connected to the composer's unfulfilled loves.

The story behind the early Violin Concerto, op. posth. (BB 48a) is well known, but there is a lesser known phase in the transformation process of the Concerto into the Two Portraits (BB 48b), when the first movement, then entitled simply "Portrait" (only later renamed as "One Ideal") was paired with the orchestration of the first Romanian Dance (BB 61). On the premiere of this version, on 12 February 1911, the soloist was Waldbauer, who performed with the Országos Szimfóniai Zenekar [National Symphony Orchestra] conducted by László Kún. $^{73}$

The Sonata for Violin and Piano no. 2 (its date of premiere, 7 February 1923, was discussed before) was composed in July-November 1922 for Jelly d'Arányi who was a former classmate of Waldbauer in Hubay's master class. She refused Bartók's advances in April that year, and after that she decided to avoid any further communication or appearances with him. Possibly this was the other factor - in addition to bad experiences with other foreign violinists - that led Bartók to try the originally Jelly-exclusive First Sonata with Waldbauer and Székely, as mentioned before. Benjamin Suchoff states that it is possible that Bartók intended to premiere the Second Sonata with Jelly and thus get into some personal contact with her again, but as he was rejected, he had to give the first performance with Waldbauer. When a tour to England could occur under the auspices of the newly formed International Society for Contemporary Music (which included a request to Jelly to perform the two sonatas with Bartók on 7 May 1923 in London), he added her initials as dedicatee of the Second Sonata - only at the end of the fair copy. $^{74}$

Naturally, we cannot rule out the possibility that it was more important for the composer that someone played his new pieces, and that he did not care too much if the first performance was given by the dedicatee or not. The Sonata for Violin and Piano no. 1 was also dedicated to Jelly Arányi and the first performance was planned with Arányi and Bartók himself. In the end, their performance was preceded by a performance by Mary Dickenson-Auner and Eduard Steuermann a month earlier. ${ }^{75}$

There is an interview with Bartók in Az Ujság [The news] on 21 January 1923 that supports this idea and Suchoff s thesis at the same time. In this interview, Bartók stated that he planned to premiere his Second Sonata with Székely on 26 February in Budapest, and it was also possible that it would not be the "Urafführung" of the work: Melos in Berlin wanted to arrange three

\footnotetext{
${ }^{73}$ In a letter sent to his mother dated 27 September 1910 Bartók writes that the Orchestra of the Academy of Music will play his Violin Concerto with Waldbauer, and, independently from that, he has to orchestrate for an orchestral concert with Kún on 4 December the following piano pieces: Romanian Dance no. 1 (BB 56/1), Evening in Transylvania (BB 51/5), Ma mie qui danse (BB 50/14, which later became the second Portrait in 1916), Romanian Dance no. 2 (BB 56/2). BARTÓK, Jr. and GOMBOCZ-KONKOLY (eds.), Családi levelei, 201-202.

${ }^{74}$ Benjamin SUCHOFF, Béla Bartók: Life and Work (Lanham, Maryland and London: The Scarecrow Press, 2001 ), 99.

${ }^{75}$ About the premiere of the Sonata for Violin and Piano no. 1, see COOPER, Béla Bartók, 162-64; SZABÓ, "Forma és jelentés," 154-155.
} 
concerts exclusively from his works in the beginning of February. Waldbauer and his Quartet would be on their journey to England, so they could join him in Berlin. ${ }^{76}$ The result was that the first performance was given by Waldbauer, the Hungarian premiere was planned with Székely in the absence of Waldbauer, but because of Székely's illness, it was eventually done by Ede Zathureczky as his first ever joint concert with Bartók. ${ }^{77}$

\section{SURVIVING COPIES OF SHEET-MUSIC EDITIONS AND PERFORMANCE MATERIALS}

Aside from fragments of their correspondence and documents linked to their concerts, some other important Waldbauer-related musical documents survive both in the American Bartók Estate, currently deposited by Peter Bartók in the Paul Sacher Foundation, Basel (hereafter abbreviated as PB) and in the Budapest Bartók Archives (hereafter abbreviated as BBA).

Bartók composed his Piano Quintet between 1903 and 1904 and performed its world premiere on 21 November 1904 in Vienna with the Prill Quartet. According to a letter-draft by Waldbauer, Bartók told him that this 1904 Vienna performance and the later unrealized 1905 performance during the Rubinstein Competition in Paris used an autograph manuscript which, in 1939, Bartók thought had been lost around 1905-1906. ${ }^{78}$ This source or these sources could be identical either with the still missing manuscripts referred to by László Somfai as "Sketches and the draft," or more probably the autograph score with layers of later corrections, which is now in the Budapest Bartók Archives (BAN: 2002a). ${ }^{79}$ This material and the autograph parts with the corrections from the score, including fingerings and bowings from Waldbauer and his colleagues (BAN: 2002b1-4) were surely used by Bartók and the Waldbauer-Kerpely Quartet in 1910 and 1921. If Bartók (and Waldbauer) really meant these sources, which is most likely, it could not have been lost in 1905-1906, in spite of the information coming from Waldbauer's letter-draft.

Denijs Dille, the editor of the first and so far only printed edition of the Piano Quintet (1970) reports in his preface that the autograph score disappeared as a consequence of an incident. As Márta Ziegler told him, on 7 January 1921 Bartók's quintet (a work from his early, already disavowed "romantic" period) had won a frantic applause and after the concert some inconsiderate members of the audience congratulated him by telling him that they preferred that music to what was composed by him subsequently. Bartók did not like it and flew into such a rage that he flung the score into a corner; Ziegler (and also Kodály) thought that Bartók had torn it up or burnt it. Dille writes that he was able to lay hands on the score and on the parts in a batch containing other unpublished works coming from Ditta Pásztory-Bartók in January 1963,

\footnotetext{
${ }^{76}$ N. N., „Mi készül zeneszerzőink műhelyében?,” Az Ujság 21/16 (21 January 1923), 7. The Waldbauer-Kerpely Quartet was on an English-Italian tour between 12 February and 6 March, see "Concert diary of the Waldbauer-Kerpely String Quartet (1910-1928),” W-VIII C-2135/16, 20-21.

${ }^{77}$ KENNESON, Székely and Bartók, 60; SZABÓ, “Forma és jelentés,” 220-221.

78“Követ úr," W-VIII

${ }^{79}$ László SOMFAI, Béla Bartók: Composition, Concepts, and Autograph Sources (Berkeley-Los Angeles-London: University of California Press, 1996), 302. See online: http://zti.hu/bartok/ba_en_06_m.htm?0301 (accessed 19 February 2018).
} 
which was then donated to the Archives in early 1965. It is not clear what happened with this material between 1921 and 1963 .

Bartók also had a copy of the piano score and the string parts made by a professional copyist to have a second set for the planned, but unrealized, Budapest performance on 4 December 1904 with the Grünfeld-Bürger String Quartet. ${ }^{80}$ This material is now preserved in Basel (PB 7FSFC1)..$^{81}$

Sándor Albrecht, a younger composer friend living in Bratislava, asked Bartók in early 1934 about the Piano Quintet, and Bartók replied on 3 March from Switzerland that when he arrived home, he would look for the duplicate (if he remembered well, and a duplicate really existed) and would send it to him. On 19 April, he repeated the same; he probably had difficulties to find the requested document. On 11 June Bartók reported that the copy of the score had earlier been bestowed to Waldbauer, but he had by then received it back and sent to Albrecht. On 15 September they arranged that when Bartók would be travelling through Bratislava on 29 November Albrecht should give the copy of the score back to him. ${ }^{82}$ As there are no further clues in the Albrecht-Bartók correspondence, it seems that Albrecht indeed must have given the copy back.

As it is reported by Waldbauer himself, the material was presented - as it seems, once again to him by Bartók in 1939. This copy was used on 13 January 1944 on the joint concert of the Waldbauer-Kerpely Quartet and Bartók's pupil György Faragó. ${ }^{83}$ The set of parts by a professional copyist preserved in Basel (PB 7PartsFC1) seems not be related to the aforementioned autograph copy and, based on their annotations, they could have been prepared for the 1944 performance.

Waldbauer took good care of the material; he saved it during the siege of Budapest and took it to the USA. This copy of the score became also a reminder of Waldbauer's personal troubles a decade later: He wanted to use the material, which he thought was the only surviving copy, in a personal-political business around 1951 in exchange for his imprisoned daughter. ${ }^{84}$ The copy of the score became part of Victor Bator's collection probably in the early $1960 \mathrm{~s}^{85}$

Waldbauer also took at least two other important Bartók-sources with him to the USA, but he managed to keep them so in secret that until 2020 the Bartók scholars had no idea that they even existed. The first is the set of manuscript parts of movement IV of the Fourth Quartet. This was originally also a test copy, like the copy of the first violin part of movement I (see below), but later became the part of the engraver's copy of the parts, of which this is the only surviving part. The second is a lithograph copy of Bartók's autograph score of the Fifth Quartet, which

\footnotetext{
${ }^{80}$ See "Követ úr," W-VIII, but Waldbauer was not sure about the date of the Grünfeld-Bürger-performance: he wrote originally 1908 which he changed to 1907.

${ }^{81}$ Photocopy in the Budapest Bartók Archives.

${ }^{82}$ Bartók Béla levelei, ed. by János DEMÉNY (Budapest: Zenemükiadó, 1976), 475, 479, 481.

${ }^{83} \mathrm{~A}$ copy of the program booklet survives in W-VIII.

${ }^{84}$ Márta Waldbauer wanted to get a visa to travel to the USA and therefore she had to communicate with the US and UK ambassadors in Hungary. This made her suspicious to the newly established communist government, and she was sent to the detention camp of Kistarcsa. Her father wanted to offer the valuable documents to the Hungarian State in exchange for his daughter. It is not known whether the undated drafts "Követ úr" [Mr. Ambassador] and "Dear Martin" found in W-VIII, which inform us about this story, were ever sent, and if so, what further actions occurred.

${ }^{85}$ Victor BATOR, The Béla Bartók Archives: History and Catalogue (New York: Bartók Archives Publication, 1963$), 22$.
} 
originally functioned as the composer personal copy, where he marked his changes prior the publication of the first edition of the score. Both sources were donated to the BBA by Katherine Waldbauer (Imre Waldbauer's granddaughter) in early 2021 and will be extensively discussed in the forthcoming volumes of the Béla Bartók Complete Critical Edition (vols. 29 and 30, to be published in 2022).

The 1911 performance material for the "Portrait" was a copy of the solo part by an unknown copyist, entitled "Violinstimme" in Waldbauer's hand (BAN: 4131c). ${ }^{86}$ This material is also significant because of the markings by Waldbauer regarding practical issues. The three most important aspects are, first, how he converted long phrasing slurs to more violinistic ones (very characteristic in the first 15 measures), and second, where he wrote in "elöre" (forward) not to hold back the tempo. The third is how much portamenti he used compared to today's performances: of the total 104 fingering that he entered $56(53 \%)$ indicate a slide with the same finger, $6(0.5 \%)$ indicate big leaps on one string under one bow stroke, and he even indicated the intermediary note for sliding in measure $26 .{ }^{87}$ Furthermore, this document is proof that Waldbauer was in the circle of colleagues who were aware of the existence of the original Violin Concerto, as this material contains both movements. It is also noteworthy that there are markings from Bartók himself - for example the "ohne Vibrieren!" (do not vibrate) at the beginning of the second movement - which do not appear in any previous or later sources. This indicates that in this phase Bartók still intended to do something with the second movement of the Violin Concerto as well.

BAN: 1084 (formerly in János Temesváry's possession) is a copy of the first violin part of String Quartet no. 4, movement I, measures 1-142 in Bartók's hand. The composer gave this sample page during the intermediary stage of the compositional process specially to Waldbauer to ask him about the playability of the difficult part. ${ }^{88}$ It is one of the several documented instances when Bartók, who also went the extra mile many times to listen to the Quartet's rehearsals, asked Waldbauer about technical solutions, even if the piece was not composed especially for him or his quartet. ${ }^{89}$

\footnotetext{
${ }^{86}$ SOMFAI, Béla Bartók, 214.; BAN: 4131c has been preserved in the Budapest Bartók Archives.

${ }^{87}$ For us today, the most extreme is the fingering for measures $91-93$, where Waldbauer marks constant slides. This was in fact not alien from Jenő Hubay or his school, see for example Hubay's fingering in Mendelssohn's Violin Concerto, movement II, measures 37-38, 85-86. Felix Mendelssohn-Bartholdy, Violinkonzert mit Orchesterbegleitung, Op. 64. Für Violine und Klavier (Budapest: Rozsnyai, s. a. [ca. 1913]). Quick writes in 1975: “... probably the most distracting mannerism that he [Waldbauer] had was the frequent use of portamenti in shifting. Not only was the sound linking the two notes obvious, but Waldbauer's shifts were even more pronounced because he often accented the last note ... Waldbauer would often stress the portamenti by gliding either from the last note of the old position, or from the intermediary note to the first note of the new position. He never used the 'modern slide' - sliding with the 'new' finger and if someone tried it, Waldbauer would admonish him for playing like a Gypsy. He also referred to them as 'Jewish slides'." QUICK, "Violin Pedagogy of Imre Waldbauer," 20.

${ }^{88}$ See the facsimile of the first page in László SOMFAI, Bartók's Workshop, Sketches, Manuscripts, Versions: The Compositional Process. Exhibition of the Budapest Bartók Archives (Budapest: Institute for Musicology, 1987), 36. See also SOMFAI, Béla Bartók, 231; BAN: 1084 has been preserved in the Budapest Bartók Archives.

${ }^{89}$ About Bartók visiting Waldbauer rehearsals, see Béla BARTÓK, Jr., Bartók Béla mühelyében [The workshop of Béla Bartók] (Budapest: Szépirodalmi Könyvkiadó, 1982), 505.; BÓNIS, Így láttuk Bartókot, 59 [Egon Kenton’s recollection]; BARTÓK, Jr., Apám életének krónikája, 162 and 276.
} 
Waldbauer's own legacy, which arrived at the Budapest Bartók Archives in 2013, contains plenty of richly marked parts that were probably used in concerts. This includes, for example, Debussy's String Quartet and the solo works by Bach in Carl Flesch's edition and dedicated to Waldbauer by the editor. The greatest significance of the collection is that it contains the first five string quartets by Bartók, which are first editions and based on the annotations were most probably used by the Waldbauer-Kerpely Quartet. ${ }^{90}$ There are also two other violin parts, which are connected to the Waldbauer-Bartók partnership: a part of the B minor Violin-Keyboard Sonata (BWV 1014) by Johann Sebastian Bach which bears the autograph marking "Bartókkal kijelölt" (annotated with Bartók), and the collection of the Mozart Violin Sonatas, where the Sonata K. 526 in A major is annotated. These sonatas were present in the repertoire of the Waldbauer-Bartók duo.

The documents mentioned above are very significant to get to know the performing style of a partly forgotten, but very close violinist colleague of Bartók from whom no recording has been known until recently. ${ }^{91}$

\section{TAKING CARE OF BARTÓK'S LEGACY}

Waldbauer was also involved in taking care of Bartók's artistic legacy. When he moved to Iowa, he sought possibilities to perform and to propagate the works of Bartók. He performed 11 pieces from the Forty-Four Duos with Marianne Mikes on 9 January 1948, the Sonata for Violin and Piano no. 2 with John Simms in a radio broadcast on 19 October 1949, String Quartet no. 1 with the faculty quartet plus Sonata for Violin and Piano no. 1 with Simms on 18 April 1951 and conducted the string orchestra-version of the Romanian Folk Dances (BB 76) on 1 March $1952 .{ }^{92}$

From 20 October 1950, he became a member of the Director's Committee of the Bartók Memorial Foundation established on 7 June $1950 .{ }^{93}$ Presumably in connection with this organization, he organized at least one memorial concert (18 April 1951) and planned a big research project on the topic of Bartók and his impact on violin technique. This would have consisted of either a long essay or several shorter essays and public presentations. Sadly, this

\footnotetext{
${ }^{90}$ The Bartók-related materials are listed in Appendix 3.

${ }^{91}$ During the last stage of writing this article, I have found - using the online ArchiveSpace of The University of Iowa Libraries -, in the University of Iowa Archives, in Philip Greeley Clapp Papers (a professor of music at Iowa 1919-1953, composer and symphony conductor) an entry about two 78 RPM discs recorded on 7 June 1948: http://aspace.lib. uiowa.edu/repositories/3/archival_objects/257669 (accessed 30 January 2018). This is the only known recording of Waldbauer. According to my correspondence with Sarah Lucas, the first disc is a recording of the first movement of Beethoven's op. 12, no. 2, perhaps from a performance for a radio broadcast (Clapp made a few remarks on the piece before he and Waldbauer played), the second disc has a recording of the third movement and a partial recording of the fourth movement of Schubert's "Trout" Quintet.

${ }^{92}$ N. N., "Faculty Recital »Hypnotically Interesting«," The Daily Iowan (10 January 1948), 6; N. N., "Music Hours Series Broadcast to Begin," The Daily Iowan (18 October 1949), 7; N. N., "Waldbauer to Play on WSUI Show," The Daily Iowan (17 April 1951), 6; "Program of Bartok Memorial Concert 18 April 1951," W-VIII; N. N., "High School Students To Attend Music Workshops Today," The Daily Iowan (1 March 1952), 3.

${ }^{93}$ N. N., "Waldbauer Named to Bartok Board," The Daily Iowan (9 December 1950), 3. (Clipping in W-VIII.) The reports of the first three meetings are also preserved in $W$-VIII.
} 
project was never completed, presumably because of his sudden death in 1952. His plan was indeed very impressive: he wanted to ask many violinists, namely Székely, Szigeti, Menuhin, Spivakovsky, and maybe Gertler, who were in close personal contact with Bartók to contribute to his project. Two letters, one for Székely and one for Szigeti, which set out the outlines of this project were written dated 13 November 1952 (less than a month before Waldbauer's death), but as they can be found in full form in W-VIII, it is not known if they were ever sent.

Some fragmentary documents of this essay plan survive. ${ }^{94}$ The most impressive and complete document relating to the planned research project is the longer Hungarian text entitled "Bartók's impact on the violin technique - based on his six quartets and two sonatas" in two versions: a 14-page-long manuscript in pencil with corrections, and a typewritten copy on 17 pages. ${ }^{95}$ This could be a first attempt to write the essay as there are many corrections in pencil on the typewritten version, and there are still some tangled parts in it, but the quotations from external sources are already inserted in English.

At the beginning of the essay, Waldbauer tries to summarize the three most influential factors at the start of Bartók's career: the knowledge of and respect for traditions, patriotism and playfulness combined with the need for exploration. He stresses the importance of Bartók's insistence in his activities and the impact of Kodály and folk music collecting. After this, he switches to sketch a short summary of the history of violin and chamber music playing. ${ }^{96}$ Then he switches back to Bartók and tells the stories of the Piano Quintet and the Two Portraits and his involvement with these pieces. Then, he summarizes the important elements of Bartók's mature style based on Mátyás Seiber's article on Bartók's chamber music. ${ }^{97}$ After that, he sets out how the violin pedagogy did not follow the evolution of modern music, and as an example he cites "the most used method," the Flesch Skalensystem, has to be completed with pentatonic, whole tone, and modal scales, and that the diatonic and chromatic scales have to be practiced in a modern way with more flexible fingerings. ${ }^{98}$ Finally, he goes through all the six string quartets and the two sonatas, and highlights the new elements in each work compared to previous works. He gives some advice for solving technical difficulties too, such as how to solve the fingerings in the first movement and bowings in the last movement of String Quartet no. 1, the big leaps in String Quartet no. 2 and in both Violin-Piano Sonatas, the percussive elements in String Quartets nos. 3 and $4 .{ }^{99}$

\footnotetext{
${ }^{94}$ See Appendix 4. Published in an edited form, with additional footnotes in NÉMETH, "Bartók-témájú írások a Waldbauer-hagyatékban," 95-112.

95“Bartóknak a hegedűtehnikára gyakorolt hatása/6 quartettjének és 2 heg.-zong. szonátájának alapján,” W-VIII.

${ }^{96}$ This is a typical, recurring element in Waldbauer's writing, not just in published ones, but also in sketches, and not limited to violinistic topics.

${ }^{97}$ Mátyás SEIBER, “Béla Bartók’s Chamber Music," Tempo 13 (Autumn 1949), 19-31.

${ }^{98}$ Carl FLESCH, Das Skalensystem (Lepizig: Peters, 1926.) According to Paul Rolland, Flesch's pedagogical works were considered and undoubtedly used by Waldbauer in his teaching. Statements made by other interviewers confirm that there was close mutual respect and sharing of knowledge between Flesch and Waldbauer, see QUICK, "Violin Pedagogy of Imre Waldbauer," 58. W-I contains a 1930 Peters edition of the Bach Sonatas and Partitas, edited by Flesch, a copy is dedicated to Waldbauer (Baden-Baden, 22 October 1930) by the editor.

${ }^{99}$ It is interesting to compare Waldbauer's solutions with Joseph SZIGETI, A Violinist's Notebook (London: Gerald Duckworth, 1964), 35-38.
} 


\section{APPENDIX 1}

The members of the Hungarian Quartet (Waldbauer-Kerpely Quartet)

\begin{tabular}{|l|c|c|}
\hline Instrument & Name & Period \\
\hline 1st Violin & Imre Waldbauer & $1910-1946$ \\
\hline 2nd Violin & János Temesváry & $1910-1923$ \\
\cline { 2 - 3 } & Béla Melles & $1923-1924$ \\
\cline { 2 - 3 } & Jenő Keszler & $1924-1927$ \\
\cline { 2 - 3 } & Tivadar Országh & $1927-1930,1935-1940$ \\
\cline { 2 - 3 } & György Hannover & $1930-1935$ \\
\cline { 2 - 3 } & Péter Szervánszky & $1935-1946$ \\
\cline { 2 - 3 } & Vilmos Tátrai (regular deputy) & ca 1942-1946 \\
\hline Viola & Antal Molnár & $1910-1912$ \\
\cline { 2 - 3 } & Egon Kornstein [Kenton] & $1912-1923$ \\
\cline { 2 - 3 } & János Temesváry & $1923-1940$ \\
\cline { 2 - 3 } & Tivadar Országh & $1940-1946$ \\
\hline \multirow{4}{*}{ Violoncello } & Jenö Kerpely & $1910-1946$ \\
\cline { 2 - 3 } & Ede Banda (regular deputy) & 1945 \\
\cline { 2 - 3 } & &
\end{tabular}

\section{APPENDIX 2}

Bartók's joint performances with Waldbauer (as violin-piano duo)

\begin{tabular}{|c|c|c|c|c|c|}
\hline No. & City & Date & Repertoire (joint) & Repertoire (other) & $\begin{array}{c}\text { Performers } \\
\text { (other) }\end{array}$ \\
\hline 1 & $\begin{array}{l}\text { Budapest, } \\
\text { Academy of } \\
\text { Music }\end{array}$ & $\begin{array}{c}20 \text { Dec } \\
1922\end{array}$ & $\begin{array}{l}\text { Bartók: Sonata No. } 1 \\
\quad(\text { BB 84) }\end{array}$ & $\begin{array}{l}\text { Bartók: Elegy no. } 2 \text { (op. 8b, } \\
\text { BB 49) } \\
\text { Bartók: Suite (op. 14, BB 70) } \\
\text { Bartók: Sonatina (BB 69) } \\
\text { Bartók: Dirge no. } 1 \text { (op. 9a, } \\
\text { BB 58) }\end{array}$ & Izabella Nagy \\
\hline
\end{tabular}

(continued)

\footnotetext{
${ }^{100}$ Hungarian premiere.
} 


\section{Continued}

\begin{tabular}{|c|c|c|c|c|c|}
\hline No. & City & Date & Repertoire (joint) & Repertoire (other) & $\begin{array}{l}\text { Performers } \\
\text { (other) }\end{array}$ \\
\hline & & & & $\begin{array}{l}\text { Bartók: Three Burlesques/no. } \\
1 \text { “Quarrel”, no. } 2 \text { "Slightly } \\
\text { Tipsy” (op. 8c, BB 55) } \\
\text { Bartók: Romanian Dance no. } \\
1 \text { (op. 8a, BB 56/1) } \\
\text { Bartók: Eight Hungarian } \\
\text { Folksongs nos. 1-5 (BB 47) }\end{array}$ & \\
\hline 2 & $\begin{array}{l}\text { Budapest, } \\
\text { Academy of } \\
\text { Music }\end{array}$ & $\begin{array}{l}1 \text { Jan } \\
1923\end{array}$ & $\begin{array}{c}\text { Bartók: Sonata No. } 1 \\
\text { (BB 84) }\end{array}$ & $\begin{array}{l}\text { Brahms: String Quartet No. } 1 \\
\text { (op. } 51 \text { no. 1) } \\
\text { Tchaikovsky: String Quartet } \\
\text { No. } 3 \text { (op. 30) }\end{array}$ & $\begin{array}{l}\text { Waldbauer- } \\
\text { Kerpely } \\
\text { Quartet }\end{array}$ \\
\hline 3 & $\begin{array}{l}\text { Berlin, Bellevue } \\
\text { Str. 6/a }\end{array}$ & $\begin{array}{l}6 \text { Feb } \\
1923\end{array}$ & $\begin{array}{c}\text { Bartók: Sonata No. } 1 \\
\text { (BB 84) }\end{array}$ & $\begin{array}{c}\text { Bartók: String Quartet No. } 2 \\
\text { (op. 17, BB 75) }\end{array}$ & $\begin{array}{l}\text { Waldbauer- } \\
\text { Kerpely } \\
\text { Quartet }\end{array}$ \\
\hline 4 & Berlin, ? & $\begin{array}{l}7 \text { Feb } \\
1923\end{array}$ & $\begin{array}{l}\text { Bartók: Sonata No. } 2 \\
\quad(B B 85)^{101}\end{array}$ & $\begin{array}{c}\text { Bartók: String Quartet No. } 1 \\
\text { (op. 7, BB 52) }\end{array}$ & $\begin{array}{l}\text { Waldbauer- } \\
\text { Kerpely } \\
\text { Quartet }\end{array}$ \\
\hline 5 & $\begin{array}{l}\text { Berlin, Grotrian- } \\
\text { Steinweg } \\
\text { Chamber Music } \\
\text { Hall }\end{array}$ & $\begin{array}{l}9 \text { Feb } \\
1923\end{array}$ & $\begin{array}{l}\text { Bartók: Sonata No. } 1 \\
\text { (BB 84) }\end{array}$ & $\begin{array}{c}\text { Bartók: String Quartet No. } 1 \\
\text { (op. 7, BB 52) }\end{array}$ & $\begin{array}{l}\text { Waldbauer- } \\
\text { Kerpely } \\
\text { Quartet }\end{array}$ \\
\hline 6 & $\begin{array}{l}\text { Košice, } \\
\text { Schalkhaus }\end{array}$ & $\begin{array}{l}5 \mathrm{Apr} \\
1923\end{array}$ & $\begin{array}{l}\text { Brahms: Sonata No. } 3 \\
\text { (op. 108) } \\
\text { Handel: Sonata in D } \\
\text { (HWV 371) })^{103} \\
\text { Franck: Sonata in A } \\
\text { Bartók: Sonata No. } 2 \\
\text { (BB 85) }\end{array}$ & & \\
\hline 7 & $\begin{array}{l}\text { Vienna, Mittlerer } \\
\text { Konzerthaus-Saal }\end{array}$ & $\begin{array}{c}240 \mathrm{ct} \\
1923\end{array}$ & $\begin{array}{c}\text { Bloch: Sonata }{ }^{104} \\
\text { Bartók: Sonata No. } 2 \\
\text { (BB 85) }\end{array}$ & $\begin{array}{l}\text { Songs by Kodály, de Falla, } \\
\text { Pizzetti }\end{array}$ & $\begin{array}{l}\text { Dorothy } \\
\text { Moulton, Paul } \\
\text { Pisk }\end{array}$ \\
\hline
\end{tabular}

(continued)

\footnotetext{
${ }^{101}$ World premiere. Performed two times during the concert.

${ }^{102}$ According to Bartók's letter to his Mother on 5 April 1923, Brahms' A major Violin-Piano Sonata op. 100 was printed in the program. Béla Bartók Letters, ed. Demény, 337-338.

${ }^{103}$ According to Bartók's aforementioned letter, the printed program consisted piano works by Bartók instead of the Händel Sonata.

${ }^{104}$ According to Béla Bartók, Jr., originally Bartók’s Sonata no. 1 was planned, BARTÓK, Jr., Apám életének krónikája, 210.
} 


\section{Continued}

\begin{tabular}{|c|c|c|c|c|c|}
\hline No. & City & Date & Repertoire (joint) & Repertoire (other) & $\begin{array}{l}\text { Performers } \\
\text { (other) }\end{array}$ \\
\hline 8 & $\begin{array}{l}\text { Budapest, } \\
\text { Academy of } \\
\text { Music }^{105}\end{array}$ & $\begin{array}{l}5 \text { Jan } \\
1924\end{array}$ & $\begin{array}{c}\text { Bartók: Sonata No. } 2 \\
\text { (BB 85) }\end{array}$ & $\begin{array}{l}\text { Kodály: String Quartet No. } 1 \\
\text { Beethoven: String Quartet in } \\
\text { C (op. } 59 \text { no. 3) }\end{array}$ & $\begin{array}{l}\text { Waldbauer- } \\
\text { Kerpely } \\
\text { Quartet }\end{array}$ \\
\hline 9 & Budapest, Radio & $\begin{array}{l}1 \text { Jan } \\
1931\end{array}$ & $\begin{array}{c}\text { Bach: Sonata in B } \\
\text { (BWV 1014) } \\
\text { Bartók: Rhapsody No. } 1 \\
\text { (BB 94a) } \\
\text { Schubert: Sonatina } \\
\text { No. } 3 \text { (op. 137, D. 408) } \\
\text { Mozart: Sonata in A } \\
\text { (K. 526) }\end{array}$ & & \\
\hline 10 & $\begin{array}{c}\text { Munich, Residenz } \\
\text { Theatre }\end{array}$ & $\begin{array}{c}14 \text { June } \\
1931\end{array}$ & $\begin{array}{l}\text { Bartók: Sonata No. } 2 \\
\text { (BB 85) }\end{array}$ & $\begin{array}{c}\text { Bartók: Ten Easy Piano } \\
\text { Piece/no. } 5 \text { "Bear Dance", } \\
\text { no. } 10 \text { "Evening in } \\
\text { Transylvania" (BB 51/5,10) } \\
\text { Bartók: Three Burlesques/no. } \\
1 \text { “Quarrel,, no. } 2 \text { "Slightly } \\
\text { Tipsy" (op. 8c, BB 55) } \\
\text { Bartók: Allegro barbaro (BB } \\
63 \text { ) } \\
\text { Bartók: Romanian Dance no. } \\
1 \text { (op. 8a, BB 56/1) } \\
\text { Songs }\end{array}$ & $\begin{array}{l}\text { Felicie Hünt- } \\
\text { Mihacsek }\end{array}$ \\
\hline 11 & $\begin{array}{l}\text { Augsburg, } \\
\text { Börsensaal }\end{array}$ & $\begin{array}{c}15 \text { June } \\
1931\end{array}$ & \begin{tabular}{|c} 
Bartók: Sonata No. 2 \\
(BB 85) \\
Bartók: Rhapsody No. 1 \\
(BB 94a)
\end{tabular} & \begin{tabular}{|} 
Bartók: Ten Easy Piano \\
Piece/no. 5 “Bear Dance," \\
no. 10 “Evening in \\
Transylvania” (BB 51/5,10) \\
Bartók: Three Burlesques/no. \\
1 “Quarrel”, no. 2 “Slightly \\
Tipsy” (op. 8c, BB 55) \\
Bartók: Allegro barbaro (BB \\
63) \\
Bartók: Romanian Dance no. \\
1 (op. 8a, BB 56/1) \\
Songs
\end{tabular} & $\begin{array}{c}\text { Annemarie } \\
\text { Kaltenbrunner }\end{array}$ \\
\hline
\end{tabular}

(continued)

\footnotetext{
${ }^{105}$ This item is missing from Szabó, "Forma és jelentés”.
} 


\section{Continued}

\begin{tabular}{|c|c|c|c|c|c|}
\hline No. & City & Date & Repertoire (joint) & Repertoire (other) & $\begin{array}{c}\text { Performers } \\
\text { (other) }\end{array}$ \\
\hline 12 & Munich, Radio & $\begin{array}{c}16 \text { June } \\
1931\end{array}$ & $\begin{array}{l}\text { Schubert: Sonatina } \\
\text { no. } 2 \text { in A (D. 385) } \\
\text { Mozart: Sonata in A } \\
\text { (K. 526) } \\
\text { Bartók-Gertler: } \\
\text { Sonatina (BB 102a) } \\
\text { Bartók-Székely: } \\
\text { Romanian Folk Dances } \\
\text { (BB 68) }\end{array}$ & & \\
\hline 13 & $\begin{array}{c}\text { Nuremberg, City } \\
\text { Hall }\end{array}$ & $\begin{array}{c}17 \text { June } \\
1931\end{array}$ & $\begin{array}{c}\text { Bartók: Sonata no. } 2 \\
\text { (BB 85) } \\
\text { Bartók: Rhapsody no. } 1 \\
\text { (BB 94a) }\end{array}$ & $\begin{array}{c}\text { Bartók: Ten Easy Piano } \\
\text { Pieces/no. } 5 \text { "Bear Dance," } \\
\text { no. } 10 \text { "Evening in } \\
\text { Transylvania" (BB 51/5,10) } \\
\text { Bartók: Three Burlesques/no. } \\
1 \text { "Quarrel," no. } 2 \text { "Slightly } \\
\text { Tipsy" (op. 8c, BB 55) } \\
\text { Bartók: Allegro barbaro } \\
\text { (BB 63) } \\
\text { Bartók: Romanian Dance } \\
\text { no. } 1 \text { (op. 8a, BB 56/1) } \\
\text { Songs }\end{array}$ & Falus Edit \\
\hline 14 & $\begin{array}{l}\text { Frankfurt am } \\
\text { Main, Radio }\end{array}$ & $\begin{array}{c}18 \text { June } \\
1931\end{array}$ & & $\begin{array}{l}\text { Bach: Sonata in B (BWV } \\
\text { 1014) } \\
\text { Mozart: Sonata in A (K. 526) } \\
\text { Bartók: Sonata no. } 2 \text { (BB 85) }\end{array}$ & \\
\hline 15 & $\begin{array}{l}\text { Budapest, } \\
\text { Academy of } \\
\text { Music }\end{array}$ & $\begin{array}{c}12 \text { Jan } \\
1934\end{array}$ & & $\begin{array}{c}\text { Brahms: Sonata no. } 2 \\
\text { (op. 100) } \\
\text { Mozart: Sonata in Bb } \\
\text { (K. 378) } \\
\text { Debussy: Sonata } \\
\text { Beethoven: Sonata no. } 9 \\
\text { "Kreutzer" (op. 47) }\end{array}$ & \\
\hline
\end{tabular}

${ }^{106}$ János Demény writes that in the sources only "Bartók: Sonatina" is given and we cannot rule out the possibility of the playing of either the First or the Second Violin Sonata. János DEMÉNY, "Bartók Béla pályája delelöjén (1927-1940)" [Béla Bartók on the peak of his career (1927-1940)], in Zenetudományi Tanulmányok vol. X, ed. by Bence SZABOLCSI and Dénes BARTHA (Budapest: Akadémiai Kiadó, 1962), 402. 


\section{APPENDIX 3}

\section{Bartók-related scores and parts in Waldbauer's legacy}

\begin{tabular}{|c|c|c|c|c|}
\hline Box & Composer & Title & Publisher & Comment \\
\hline W-I & $\begin{array}{l}\text { Bach, J.S. - ed. } \\
\text { David, Ferd. }\end{array}$ & $\begin{array}{c}\text { Sechs Sonaten für } \\
\text { Pianoforte und Violine, } \\
\text { nos. } 1-3\end{array}$ & $\begin{array}{l}\text { C.F. Peters, Leipzig Nr. } \\
\text { 232, Plate Number } \\
7281 \text { (orig. ca. 1864, } \\
\text { revised in ca. 1888) }\end{array}$ & $\begin{array}{l}\text { Title page, Waldbauer } \\
\text { ms.: "Bartókkal } \\
\text { kijelölt" [Annotated } \\
\text { with Bartók]. Only } \\
\text { BWV } 1014 \text { and the } \\
\text { first movement of } \\
1016 \text { is annotated. }\end{array}$ \\
\hline W-I & Bartók, B. & $\begin{array}{l}\text { 1. Quatour à cordes, } \\
\text { op. } 7 \text { (1908) }\end{array}$ & $\begin{array}{c}\text { Rózsavölgyi \& Cie, } \\
\text { Budapest, Plate Number } \\
\text { 3287a-d (@1911) }\end{array}$ & $\begin{array}{c}\text { Parts annotated by } \\
\text { the members of the } \\
\text { Waldbauer-Kerpely } \\
\text { Quartet. }\end{array}$ \\
\hline W-I & Bartók, B. & $\begin{array}{l}\text { 1. Quatour à cordes, } \\
\text { op. } 7 \text { (1908) }\end{array}$ & $\begin{array}{c}\text { Rózsavölgyi \& Cie, } \\
\text { Budapest, Plate Number } \\
\text { 3287a-d (@1911) } \\
\text { [Stamp:] In die } \\
\text { Universal-Edition } \\
\text { Aufgenommen No. } 6856\end{array}$ & $\begin{array}{l}\text { Parts annotated by } \\
\text { the members of the } \\
\text { Waldbauer-Kerpely } \\
\text { Quartet, only minor } \\
\text { annotations in Violin } \\
1 \text { and Violoncello; } \\
\text { possibly used later. }\end{array}$ \\
\hline W-I & Bartók, B. & $\begin{array}{l}\text { 1. Quatour à cordes, } \\
\text { op. } 7 \text { (1908) }\end{array}$ & $\begin{array}{c}\text { Rózsavölgyi \& Cie, } \\
\text { Budapest, Plate Number } \\
\text { 3287a-d (@1911) }\end{array}$ & Unused. \\
\hline W-I & Bartók, B. & $\begin{array}{l}\text { II. Streichquartett, } \\
\text { op. } 17\end{array}$ & $\begin{array}{l}\text { Universal-Edition, Plate } \\
\text { Number U.E. 6372a- } \\
\text { d (@1920) }\end{array}$ & $\begin{array}{c}\text { Parts annotated by } \\
\text { the members of the } \\
\text { Waldbauer-Kerpely } \\
\text { Quartet. }\end{array}$ \\
\hline W-II & Bartók, B. & Illème Quatuor & $\begin{array}{l}\text { Universal-Edition, Plate } \\
\text { Number U.E. 9598a- } \\
\text { d (@1929) }\end{array}$ & $\begin{array}{c}\text { Parts annotated by } \\
\text { the members of the } \\
\text { Waldbauer-Kerpely } \\
\text { Quartet. }\end{array}$ \\
\hline W-II & Bartók, B. & Illème Quatuor & $\begin{array}{c}\text { Universal-Edition, Plate } \\
\text { Number U.E. 9598a- } \\
\text { d (๔1929) }\end{array}$ & Unused. \\
\hline W-I & Bartók, B. & IVème Quatuor & $\begin{array}{c}\text { Universal-Edition, Plate } \\
\text { Number U.E. 9789a- } \\
\text { d (@1929) }\end{array}$ & $\begin{array}{l}\text { Parts annotated by } \\
\text { the members of the } \\
\text { Waldbauer-Kerpely } \\
\text { Quartet. Viola part is } \\
\text { fragmentary (only first } \\
\text { and last page). }\end{array}$ \\
\hline
\end{tabular}

(continued) 


\section{Continued}

\begin{tabular}{|l|c|c|c|c|}
\hline Box & Composer & Title & Publisher & Comment \\
\hline W-II & Bartók, B. & V. Streichquartett & $\begin{array}{c}\text { Universal-Edition, Plate } \\
\text { Number U.E. 10737a- } \\
\text { d (@1936) }\end{array}$ & Unused. \\
\hline W-II & $\begin{array}{c}\text { Bartók, B., Kadosa, } \\
\text { P., Jemnitz, A. } \\
\text { (Hg. Doflein, E.) }\end{array}$ & $\begin{array}{c}\text { Spielmusik für Violine, } \\
\text { Neue Musik, Heft IV. } \\
\text { Ungarische Komponisten } \\
\text { B: Bartók: Sieben Duette } \\
\text { über Volkslieder u. Tänze, } \\
\text { Kadosa: Vier Duette, } \\
\text { Jemnitz: Partita }\end{array}$ & $\begin{array}{c}\text { B. Schott's Söhne, } \\
\text { Mainz (@1932) }\end{array}$ & $\begin{array}{c}\text { Minor annotations in } \\
\text { the Bartók duos. } \\
\text { Maybe they were the } \\
11 \text { duos played on 9 } \\
\text { January 1948? }\end{array}$ \\
\hline W-IV & $\begin{array}{c}\text { Mozart, W.A. - ed. } \\
\text { Hermann, Fr. }\end{array}$ & $\begin{array}{c}\text { Sonaten für Pianoforte und } \\
\text { Violine }\end{array}$ & $\begin{array}{c}\text { C.F. Peters, Leipzig } \\
6952 \text { (orig. ca. 1887, } \\
\text { new edition ca. 1900?) }\end{array}$ & $\begin{array}{c}\text { Violin part only. } \\
\text { Sonatas K. 377 and } \\
\text { K. 526 are annotated. } \\
\text { This could be the part } \\
\text { Waldbauer used with } \\
\text { Bartók. }{ }^{107}\end{array}$ \\
\hline
\end{tabular}

\section{APPENDIX 4}

Fragments of Waldbauer's research project on Bartók and his impact on violin technique (documents surviving in W-VIII)

\begin{tabular}{|l|c|c|}
\hline Title & Content & Type \\
\hline & $\begin{array}{c}\text { About Bartók's and Waldbauer's } \\
\text { professional connections, in } \\
\text { Hungarian, partly in English. Sketch } \\
\text { for a planned article or a letter- } \\
\text { draft to Halsey Stevens? }\end{array}$ & 108 page written in pencil, draft \\
\hline & $\begin{array}{c}\text { About Waldbauer's first encounter } \\
\text { with Bartók, with many self- } \\
\text { references and personal } \\
\text { recollections, in Hungarian. Sketch } \\
\text { for a planned article? }\end{array}$ & \\
\hline
\end{tabular}

(continued)

\footnotetext{
${ }^{107}$ NB: Waldbauer played this Sonata with Philip Greeley Clapp on 23 April 1947 in Iowa.

${ }^{108}$ Waldbauer sent information to Stevens' Bartók biography, see Halsey STEVENS, The Life and Music of Béla Bartók (New York: Oxford University Press, $\left.{ }^{1} 1953,{ }^{2} 1964\right)$, xiii.

${ }^{109}$ Page 7 contains remarks about missing scores from the Faculty.
} 


\section{Continued}

\begin{tabular}{|c|c|c|}
\hline Title & Content & Type \\
\hline $\begin{array}{l}\text { “Bartók zeneszerzői hatása és } \\
\text { befolyása a vonóshangszerek } \\
\text { technikájára” [The Influence of } \\
\text { Bartók's Compositions on Violin } \\
\text { Technique] }\end{array}$ & $\begin{array}{l}\text { The general outline of a planned } \\
\text { article - the first sentences for an } \\
\text { Introduction - without continuation, } \\
\text { in Hungarian. }\end{array}$ & 1 page written in pencil, draft \\
\hline \multirow{2}{*}{$\begin{array}{l}\text { “Bartóknak a hegedútehnikára } \\
\text { gyakorolt hatása/6 } \\
\text { quartettjének és } 2 \text { heg.-zong. } \\
\text { szonátájának alapján” [Bartók's } \\
\text { Influence on Violin Technique: } \\
\text { on the Basis of His Six String } \\
\text { Quartets and Two Sonatas for } \\
\text { Violin and Piano] }\end{array}$} & \multirow{2}{*}{$\begin{array}{l}\text { About Bartók's impact on the violin } \\
\text { technique, in Hungarian, external } \\
\text { quotations inserted in English. }\end{array}$} & $\begin{array}{l}14 \text { pages in pencil with } \\
\text { corrections }\end{array}$ \\
\hline & & $\begin{array}{l}17 \text { pages typewritten with } \\
\text { corrections in pencil }\end{array}$ \\
\hline $\begin{array}{l}\text { “Kedves Barátom!” [My Dear } \\
\text { Friend!] }\end{array}$ & $\begin{array}{c}\text { Letter to Zoltán Székely in } \\
\text { Hungarian, dated } 13 \text { November } \\
1952 .\end{array}$ & 2 pages (letter) in ink \\
\hline $\begin{array}{l}\text { “Kedves Barátom!" [My Dear } \\
\text { Friend!] }\end{array}$ & $\begin{array}{c}\text { Letter to Joseph Szigeti in } \\
\text { Hungarian, dated } 13 \text { November } \\
1952 .\end{array}$ & 2 pages (letter) in ink \\
\hline
\end{tabular}

Open Access. This is an open-access article distributed under the terms of the Creative Commons Attribution 4.0 International License (https://creativecommons.org/licenses/by/4.0/), which permits unrestricted use, distribution, and reproduction in any medium, provided the original author and source are credited, a link to the CC License is provided, and changes - if any - are indicated. (SID_1) 